\title{
The Odal and its Manifestation in the Landscape
}

\author{
Torun Zachrisson
}

\begin{abstract}
The concept odal can be regarded in a narrow sense, i.e. as the inherited landed property of a family. But here it is argued that odal should be viewed in a wide sense - as a mentality that is of great importance to the understanding of Late Iron Age society in Sweden. The article focuses on the material expressions which belonging to a family and possessing a farm could take in the individual farmstead in the Mälar Valley. The Viking Age is interpreted as a time period in which there was a need to make the odal visible. The acts of burying dead relatives on top of the graves of early ancestors, erecting runestones, and possibly also erecting mounds are regarded as ways of guarding, marking, and confirming the possession of the odal in the odal man's own eyes and in his neighbours' and consequently also the odal man's position in society.
\end{abstract}

Torun Zachrisson, Department of Archaeology, Stockholm University, S-106 91 Stockholm, Sweden.

The complex concept odal and its signification in Iron Age society is hard to grasp since it falls within several different scientific traditions: history, human geography and archaeology. Historians have treated one side of the concept, human geographers have partly touched upon it, while archaeologists have not defined it clearly. This article aims at revealing the material forms through which one expressed belonging to a family and possessing a farm in the Mälar Valley during the Late Iron Age.

In the scientific literature odal usually means the inherited landed property of a family (Taranger 1907:381, cp. Taranger 1913: $159 \mathrm{f}$ and Rafnsson 1974:142f). The Franks' and other Germanic peoples' term for odal was allod which essentially seems to correspond to the meaning of the concept odal (Gurevich 1985:46). Odal could also comprise waters and stationary fishing works that be- longed to the land (Robberstad 1967:493, Hafström 1967:502). The word odal in the context of language is related to words like adel (nobility) and ädel (noble) (Robberstad 1967:493 and oral information from Helmer Gustavson, Head of the Section of Runes, Central Board of National Antiquities, March 1993). The last rune in the older Germanic 24-rune system bears the name odal (Erikson \& Strid 1991:24). The runes are considered to have appeared some time during the Roman Iron Age in southern Scandinavia (Gustavson 1987a:50f, cp. Palm 1992:18). The etymology of the word is unclear, but it may indicate some kind of identification with the inherited land and the ancestors from whom it ultimately derived (Foote \& Wilson 1970:82).

This view of the relationship between the land and its owner is present in the Nordic mythology. Gods are described in the same 
way as people in the Norse literature i.e. they are always referred to as whose son they are and where they come from; both people and gods are expected to possess a farm (Gurevich 1985:46f). The farmstead is such a central structure in the Nordic society that the whole cosmos was organized as one. The world was compared to a farm, with its infield lands and its outlying lands. Midgård, the middle enclosure and man's dwelling place, symbolized the claimed and cultivated part of the world. Its uncontrolled opposite was Utgård, where giants and chaos ruled (Gurevich 1985:47).

The Russian historian Aron J. Gurevich is of the opinion that odal should be regarded as a mentality, which is fundamental to the understanding of Late Iron Age society. This is also my point of departure. It is therefore of interest to try to trace the consequences that the meaning of the odal could have for the individual farmstead or village and the material expressions that this could take. Snorre Sturluson, in his Edda, gives us kenningar poetical metaphors for yeoman odalman: property-giver, property-custodian and men's re-conciliator (Snorres Edda 1978:120). This article treats the odalman in his character of property-custodian ( $\mathrm{Sw}$. egendomsvårdare).

In the legal tradition of the Nordic countries, as it is expressed in the early medieval provincial laws and one Norse national law, the sons inherited shares in odal land while the daughters inherited outlying land (Sjöholm 1988:128). In the Norse Magnus Lagaböter's National Law from the 1270s it is stated, for example, that daughters should have goods or outlying land, that is, land that was not included in the odal rights, while sons and grandsons should inherit odal land (Robberstad 1967:497). The eldest son should have the main farmstead, the manor - attesätet (Robberstad 1967: 497). Among women, sisters and daughters could, in certain instances, inherit odal land (the Gulatings Law, Robberstad 1967:496). The odal right in the early medieval period was a right to buy in advance; even earlier, odal land was not to be sold except when necessity forced one to do so (e.g. the Gulatings Law and the Frostatings Law, Robberstad 1967:496, Hafström 1962: 658 and Rosén 1962:659). One was not all owed to dispose of inherited land without first having offered it to one's nearest relations (e.g. Older and Younger Västgöta Laws, the Land Laws Ä VgL: JB 3, Y VgL: JB 4-6, Holmbäck \& Wessén 1979). In cases where the odal farm had been unlawfully sold, the odal men had a right to redeem it from the buyer (the Gulatings Law, Robberstad 1967:496). Odal land could be divided, socalled opalskipti; something which is mentioned in, for example, the Gulatings Law och the Västgöta Laws (Robberstad 1967:493, Hafström 1967:503). To be odalsmadr - that is, to possess odal - stated what wergild should be demanded for a man, in reality his value, and it assigned him his position in society (Robberstad 1967:493ff, see further the Gulatings Law Norges Gamle Love. I:67, the Frostatings Law Norges Gamle Love. I:172). In the penalty texts such a man is called odalboren man or hauld (Björkvik 1957:67ff). Snorre Sturluson writes in his Edda (c. 1220) that odal men are "farmers who are thoroughly legitimite as to family and property" ("bönder som är fullgilla till ätt och äganderätt" Snorres Edda 1978: 120).

The odal most likely had a connection with ancestral cult since it turns to the first ancestor in the grave-mound, called haugbonden or haugbuen, i.e. the dweller or farmer of the mound (Robberstad 1967:494). In the Norse national law from the 1270 s, Magnus Lagaböter's Land Law, it is stated that a third of the goods found in the ground should go to the hogodalsmannen. The expression hogodalsman should allude to the person whose ancestor is buried in a grave-mound in the farmyard, especially the odal mound (Robberstad 1967: 497, with reference to Taranger 1934-36:124, cp. Ringstad 1991). This connection is illustrated in the cases where one's 
odal rights were questioned. In a Norse legal case in the 14th century a person was asked to count the generations "til haugs ok til heidni," i.e. back to the mound and heathendom (Norges Gamle Love. III:120). Land that had been inherited through six generations was counted as odal in Norway, judging by the Gulatings Law. According to the Frostatings Law, land was counted as odal land if it had been inherited through four generations. Since the Gulatings Law is dated to the beginning of the 12 th century and the Frostatings Law to the end of the same century, historians consider that the earlier rigorous demands on odal had been somewhat eased at the beginning of the medieval period (Lindkvist 1979: 142).

But odal could also be given a wider meaning. About Olav Tryggvason it is said that he was "odalborinn til konungsdoms," odal's heir to the kingdom (Heimskringla. II 1893-1900:54). The Norwegian kings counted the kingdom as their odal and their mounds were the visible proof of this (Rafnsson 1974:196f). Just like any other odal farm, the royal estate had its mounds in the yard (Taranger 1934-36:124).

In the world of the myth, odal is connected with the grandest representatives of society. In the Edda poem "Rigsthula" the god Heimdal in Rig's guise lets Jarl "own odal grounds, his good odal, the old settled country" "äga odalvallar, hans goda odal, den gamla bygden" (verse 36). "Then he (Jarl, my remark) alone owned eighteen farms..." "Så ägde han (Jarl, min anm.) ensam aderton gårdar..." (verse 39). "Together with Rig, Jarl got to compete in runic knowledge and reached farther in cunning and knowledge; then he got odal and was considered worthy to be called Rig, because he knew runes" "Med Rig fick Jarl i runvett tävla och nådde längre i list och kunskap; då fick han odal och aktades värdig att kallas Rig, ty han kunde runor" (verse 46, Den poetiska Eddan 1972: 152). The picture that is outlined is one in which Jarl is taught to bear weapons, ride, be generous with his possessions, and marry the daughter of a herse (local leader, originally probably a military leader, see Foote \& Wilson 1970:129). The poem speaks of the inherited estate and how the family is enlarged. Jarl's children, for instance, are named Arve and Adal (inheritance and noble) (verse 42, Den poetiska Eddan 1972:151ff). It is worth noting that in both verse 36 and 46 owning odal land is connected with runic knowledge.

It is possible that the god Thor not only was the defender of the world of man, Midgarrd, but that he also functioned as the protector of the odal. Reasons for this could be that Thor's mother bears the name Earth and that Thor's wife is called Sif, that is "kinship or relation by marriage" (Snorres Edda 1978:95, 103 and Den poetiska Eddan 1972: 339). In the Edda poem Voluspa it is further said about Thor, the slayer of the Midgård serpent: "Him (referring to the serpent, my remark) slays the one who has defended Midgård. Now every man must break up from his odal" "Honom (syftande på ormen, min anm.) dräper den som värnat Midgård. Nu må alla män bryta upp från sin odal" (verse 56, Den poetiska Eddan 1972:49). Maybe it is against this background, i.e. Thor as the protector of the odal, that the depositions of amulettes inside Viking Age buildings should be viewed.

\section{ODAL AS A MENTALITY}

The Norwegian place-name scholar and archaeologist Magnus Olsen is of the opinion that the most essential thing concerning the farm as a social institution is the odal land (1926:15). He touches upon the question of the evaluations that originate in how one apprehends the odal. Aron J. Gurevich, in his book "Categories of Medieval Culture," has given the concept odal a broader meaning than is current. He has tried to define the cultural categories of the medieval period, the building-blocks of its world-view. In order to identify these, he first defines the cultural 
categories of the heathen periods on the basis of the Scandinavian early medieval culture as it is reflected in the Norse literature (Gurevich 1985:19). In doing so, he puts the heathen man's world-view against medieval man's. The odal not only stood for the inherited land but it also legitimized the free man's rights in society. The odal right was not dependent on the size of the land, but was a function of the possessor of the odal and his relation to the generations that had preceded him (Gurevich 1985:45ff). The landed property was tied to the human collective by indissoluble bonds. Gurevitj expresses it thus: the man possessed the farm, but at the same time the farm possessed him (1985:48).

To recapitulate the above: by being a member of a family (collective) consisting of living and dead relations, you were in possession of odal rights. Therefore, care of the ancestors was embodied in the odal concept. This care could find expression in cult ceremonies linked to their graves (cp. Birkeli 1943, 1944). In the Norwegian law texts from the early Middle Ages there is a ban against sacrifice blot, that is, to offer upon gravemounds (the Gulating's Law, Brendalsmo \& Røthe 1992:96). The Church tried to obtain power over the heathen cult praxis, including the custom of sitting out, utesitje, during the night in order to call forth and question dead ancestors from the graves. In the law texts these ancestors were called mound-dwellers högbor, and the practice was called waking up mound-dwellers väcka upp högbor (Brendalsmo \& Røthe 1992:92f).

The odal man's authority was exercised from the high seat högsätet, which was the most prestigious place in a house and normally situated at the northern long wall (Carlsson 1935, Holmqvist 1962). When an odal man died his high seat remained empty until the inheritance ale, with its commemoration toasts over the dead, had been drunk. After that the son was led forward to his father's high seat. By this ritual the son inherited everything from his father (the
Gulating's Law, Taranger 1934-36:120, cp. chapter 36, the Ynglinga Saga, Snorre Sturluson 1991:61 and note 80). Wilhelm Holmqvist has suggested that the amulettes in the form of block-chairs kubbstolar, which figure among the archaeological finds, could symbolize the high seat (1962).

For the odal men of a farm there was consequently reason to defend the farm itself with its yard and infields and to defend the cemeteries of their ancestors who had made it possible for them to live on the lands. Around these different parts of the farm's microcosmos, ritual activities presumably took place. These activities probably were for the purpose of confirming and strengthening the possession of the odal and thereby the position of the odal man in his own eyes as well as those of his neighbours. Some of these activities are described in the Norse literature and in older Norse laws. Others we can learn about by looking for the material traces which they have left.

\section{BELONGING TO A FARM OR A VILLAGE IN VIKING AGE RUNIC INSCRIPTIONS}

Odal seldom occurs in runic inscriptions, except for some inscriptions from Sweden and Norway. The most well-known evidence of odal in the Mälar Valley is found on a rock at Nora in Danderyd parish in Uppland, which Björn Finnvidsson had hewn after his brother: "This is their odal and ancestral inheritance, Finnvid's sons of Älgesta" "Denna gård är deras odal och ättearv, Finnvidssönernas på Älgesta" (upal uk atarfi U130, cf. Jansson 1976:97). Why was it necessary to state "odal and ancestral inheritance"? Were the words synonymous and in that case was repetition intended to give extra power to the expression? Or have the words had different meanings? Elias Wessén and S.B.F. Jansson state in their interpretation of the inscription that arve in both ancient Swedish and Danish implies inheritance ale arvöl, as well as inheritance, 
inherited estate, landed estate and estate arv, arvegods, jordagods och fastighet. In Icelandic it implies both inheritance ale and heriditary estate. Wessén \& Jansson consider the word to originate from a common Germanic word for inheritance, arv, which, under the influence of Icelandic, has partly been replaced by the meaning inheritance ale arvöl (Jansson \& Wessén 1940-58:194f). This means that the ancestral inheritance ättearv would stand for the more concrete of the two words and be synonymous with the inheritance itself as well as with the ritual - the inheritance ale arveölet - by which the inheritance was handed over to the next generation. Odal with this reasoning would stand for the more abstract of the two and should consequently signify the odal right.

The concept odal is probably mentioned on a known but missing rune stone from Eneby in Runtuna parish in Södermanland on which it is said that: "Toke owned half the village, Grimulv half the village as old odal" "Toke ägde halva byn, Grimulv halva byn (gården) som gammal odal" (Brate \& Wessén 1924-36, odal is translated as inherited land släktjord, but on the stone it says upali Sö145). In Åkerby parish in Uppland there is an Odalfrid who erected a runestone (U1067). Odal occurs in this case as a personal name; it is, however, unclear whether it is a man's or a woman's name. At Oddernes in Vest Agder in Norway a man - Øivind- erected a rune stone with the inscription telling how he - Saint Olav's

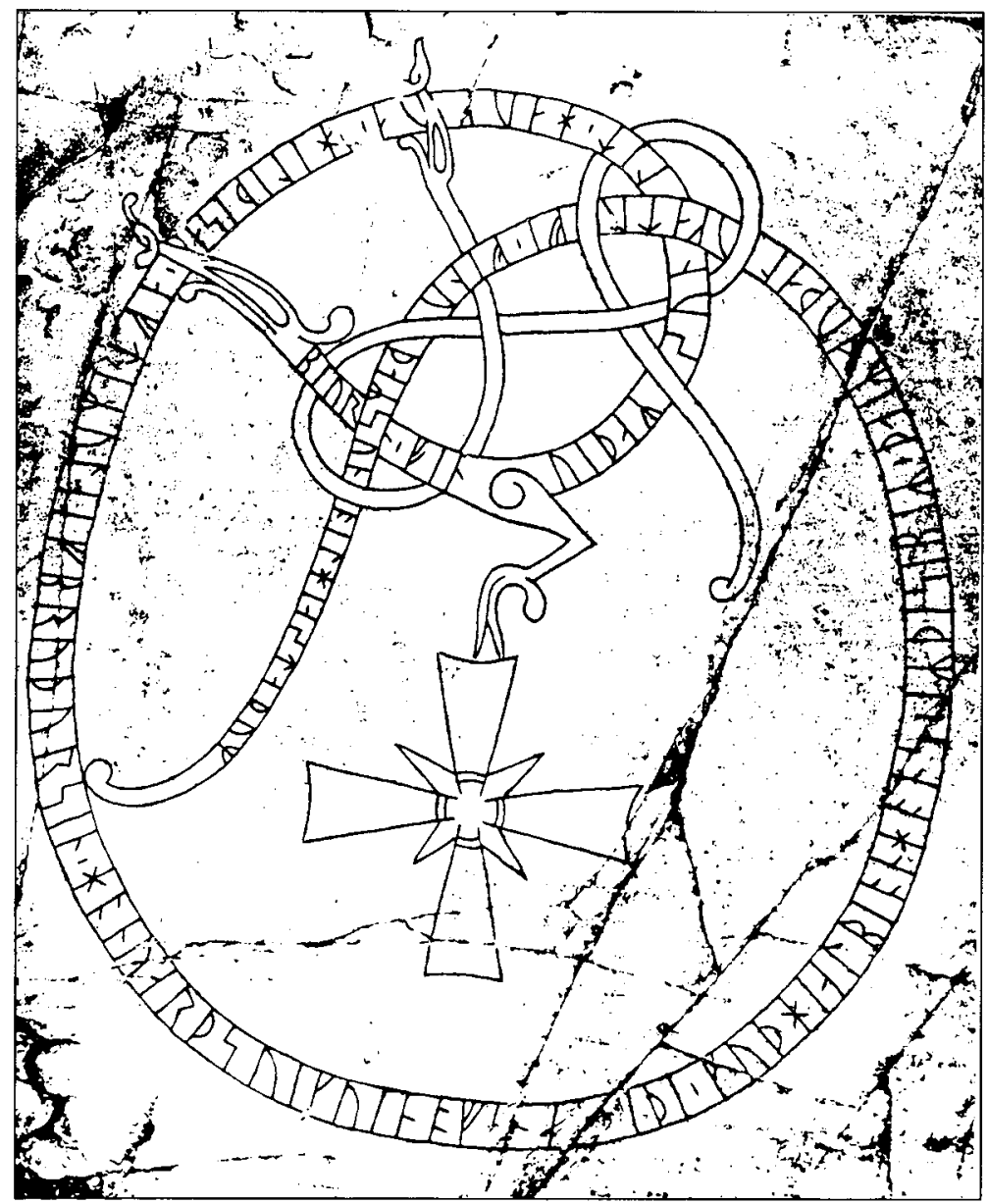
godson Olav den $\mathrm{Hel}$ liges gudsønn - had a church built on his odal odel. This $\varnothing \mathrm{i}$ vind is probably identical with the Øivind Urarhorn, born c. 985 , who is mentioned in Snorre Sturluson's Nordic Kings' Sagas (nr 210, Norges innskrifter. III. 1954:80). In Rogaland in Norway the inscription on the Sele stone mentions agreement on fishing places in which both own and odal occur

Fig.1. The inscription from Nora in Danderyd parish, Uppland (U130). The expression $\mathrm{NPtN} \wedge \mathrm{H}$ $\nmid \uparrow R$ H' upal uk atarfi is found at the animal's tail. 
(- at aign auk at opli - nr 236, Norges innskrifter. III. 1954:189).

There are additional runic inscriptions that indirectly seem to allude to odal rights or to a striving to show such legitimacy. The Malsta stone in Hälsingland and the Sandsjö stone in Smaland both count five and six generations, respectively, back in time; this can be compared with the above-mentioned statments in the Gulatings and Frostatings Laws (Jansson 1985:25B, langfaedrgar - förfäder ancestors, $\mathrm{Sm} 71$ ). A rune stone from Kärnbo deserted church in Södermanland, with partly destroyed inscription, mentions female ancestors in three generations (lang$m \phi \partial r g u$ - stammödrar, female ancestors, Sö176C).

In the Mälar Valley as well as in other places it was urgent to communicate one's affilation with a farm or a village in runic inscriptions. In some cases this was done without defining the relation between the man and the place he inhabited in more detail. One mentioned oneself or was spoken of by one's personal name and a place-name, for example: Torsten $i$ Skyttinge, Ugg i Svanby or Ulv i Skalhamra (male name in combination with place-name: Sö84, Sö104, Sö132, U18, U29, U92, U130, U161, U189, U203, U236, U 258, U338, U371, U382, U527, U593, U638, U799, U818, U999, U1146, U1172; excerpted from von Friesen 1930 and Larsson
1990:20, Table 1, the material is from Upplands, Södermanlands and Västmanlands runinskrifter).

In other cases the inscriptions are more detailed and mention that someone owns the village or that someone inhabits the village: "They owned the village Släbro, Frösten (and) Rolf..." "De ägde byn Släbro, Frösten (och) Rolf..." (Sö367). Both Otto von Friesen and Klaus Düwel have made compilations of these inscriptions but without making a closer analysis of the objectives behind them (von Friesen 1930, Düwel 1977). In S.B.F Jansson's view, the reason for stating that one owns the village is to confirm the ownership of the land (1976:97). Here a less direct interpretation than Jansson's can be applied, namely, as a way of maintaining one's disposal rights (hävda dispositionsrätt). (To own a village or a farm or an area: æeiga $=$ Sö145, Sö202, Sö367, U114, U127, U164, U165, U212A, U212B, U261, U331, U337, U348, U414? damaged, U973? uncertain as to village, damaged, Vg4, Ög82, Ö137. Mention of the word village: $b y r=\mathrm{Sö145,} \mathrm{Sö367,} \mathrm{U130,}$ U209, U331, U729, Jansson1985:25B, Vg4, Ö137. To inhabit a place or reside at a place: boa, bygga = Sö189?, Sö195, Sö208, Sö214, Sö312, U57, U114B, U160, U336, U355, U508, U649, U703, U710, U729, U744, U755, U805, U809, U932?, Gustavson 1987b:134, Ög28, Ög60, Ög94, Ög132, Ög198. Together with

Fig.2. The rune stone from Eneby in Runtuna parish, Södermanland (Sö145 A, $B)$. The word odal MPNII seems to have been given special importance in the composition of the second part of the inscription. It is placed in the middle row of side $B$ (to the right in the picture).

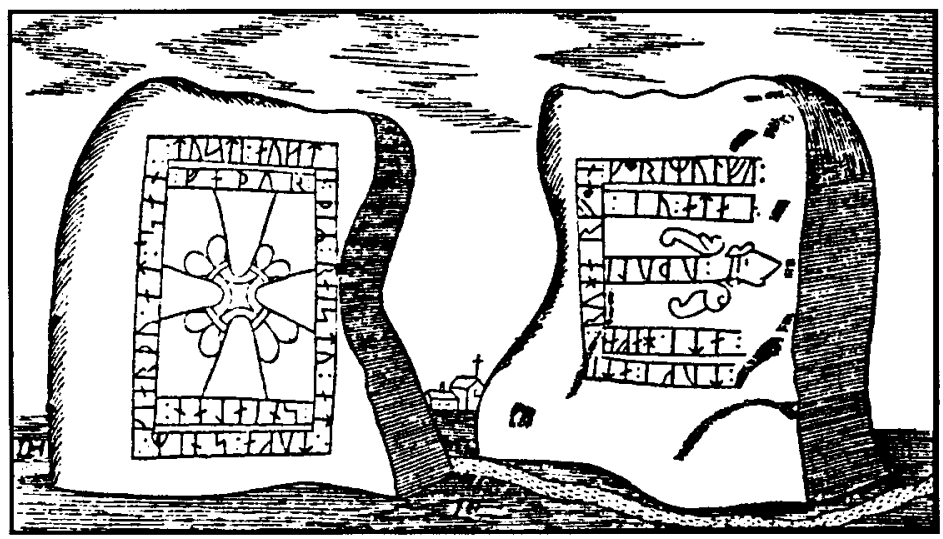


live, inhabit, reside bo, bygga there is usually a place-name, for example, "he inhabited Kälsta," "han bodde i Kälsta" [U755]. Bo, bygga + place name = Sö195, Sö208, Sö214, Sö312, U57, U114, U160, U336, U355, U508, U649, U703, U710, U729, U744, U755, U805, U809, U932, Gustavson 1987b:134, Ög28, Ög60?, Ög94, Ög132, Ög198. The compilations are excerpted from Peterson 1989, the material is from Sveriges runinskrifter, see also Gustavson 1987b:135, note 7 , notice however that Sö198, must be a miswriting for Sö 189).

In the literature on rune stones, bo and bygga are considered synonymous. They are the present and past tense of the strong verb boa. There is a possibility that the expression "they both resided in Borresta" "de byggde bada i Borresta" (U336) not only refers to having lived in Borresta but also implies having first settled at a place; first in the sense of being the first of a family to have settled in a village or a farm.

Some runic inscriptions state that somebody alone owned a village or an area. Some of these inscriptions concern Jarlabanke and they refer to a district: "He alone owned Täby" or "He alone owned the whole hundred" han ägde ensam Täby, or att han ägde ensam hundaret (U127, U164, U212A,B, U261). The others are of the type, "Ragnfast alone owned this village after his father Sigfast" "Ragnfast ägde ensam denna by, efter Sigfast sin fader" (referring to Snåttsta village, but since the inscription is placed on a rock in the village yard the information that it concerns Snåttsta is unnecessary, U331) or "Finnvid alone owned everything first" "Finnvid ägde ensam allt först" (referring to Hyppinge, or possibly Granby or both, situated in a Viking Age settlement, U337). (Äeinn (alone), to own a village, farm or district alone $=\mathrm{U127}$, U164, U212A,B, U261, U331, U337; excerpted from Peterson 1989, the material is from Sveriges runinskrifter.) But there are also runic inscriptions that state that someone owns half a village. The rune stone at Lerkaka on Öland tells: "Unn owned half the village" "Unn ägde halva byn" (Ö137). On a rune stone from Eneby in Runtuna parish in Södermanland it is said that Toke owned half the village and Grimulf half the village (Sö 145). The Släbro inscription in the same province gives us the names of the two men who owned the village of Släbro, Rolf och Frösten (Sö367). About Ulv and his uncle Onäm in Orkesta parish in Uppland it is said that they both lived in Borresta (U336). Björn Finnvid's son states that Nora in Uppland was his and his brother Olev's odal and ancestral inheritance (U130); he further more calls himself and his brother Finnvid's sons of Älgesta-Finnvidssönerna på Älgesta; they possibly also owned Älgesta together. (To own half a village $=\mathrm{Sö145,Sö367,}$ U130, U336, Öl37.)

These runic inscriptions can be read as a manifestation of an odal right. But in some cases there is also the possibility that all erectors of rune stones were not included in the odal rights, but would be so in a few or several generations time (cf. the inscription on the Veda rock in Uppland U209 which is an extreme since it states that the farm was purchased). In these cases the information on persons belonging to a farm or a village can be a manner of asserting a right that is not evident. The above-mentioned runic inscriptions may also be used to show that the division of odal land has taken place. This is seldom mentioned in the scientific literature. But Ottar Rønneseth is of the opinion, concerning the prehistoric farms of Jaeren, that in the cases where two farms are found on each side of a farmyard it may be a question of odalsskipti (Rønneseth 1975:181). With regard to the rune stone from Orkesta, a division of the odal might have occurred in an earlier generation since an uncle and a nephew inhabit the village. In the case of Finnvid's sons there is a possibility that they themselves have carried through such a division of odal land. 
THE MOUND - ONE OF THE MATERIAL EXPRESSIONS OF THE ODAL?

In disputes about land ownership rights there occurs in the provincial Östgöta Law and the Västgöta Law the expression" barrow-village and heathen village" "Høgha byr ok hepnu byr" and "høghae byr ok af hepnu bygdaer" (cp. Selinge 1980:294). These expressions denote villages that have an older vindication to the land than younger fencedoff villages. Klas-Göran Selinge, in his survey over what Iron Age man called the graves, noted that only mounds occur as a designation for prehistoric graves. He thinks this is possibly because the mound was the most common type of grave at the end of the prehistoric period, though he does not exclude other reasons (1980:294). Selinge shows from Hjalmar Falk's compilation of the Norse literature's expressions for graves that free men primarily were buried in mounds (1980:295, with reference to Falk 1913). In the examples alluded to above concerning disputes about the rights to land or the allotment of land, mound hög occurs as the designation for graves. The reason for this may be that the mound was the most common type of grave during the Late Iron Age. But here the other possibility will be discussed; namely that it really was the grave-type mound hög that was meant. Can the mound, above all other grave-types, especially have been connected with odal rights, i.e. odal men or potential such? A shipsetting skeid may have been associated with totally different persons than odal men during its own time. The triangular stone-setting also seems to be a grave form that is reserved for men (Carlsson 1990:36), but what kind of men? Snorre Sturluson writes in his Ynglinga Saga that when Odin makes laws "over noble men one should make a mound in memory" "över ädla män skulle man göra hög till minne" (1991:31 Karl G. Johansson's translation, Emil Olsson's translation from 1919 runs "after prominent men" "efter framstående män" Olsson 1919:21; the original reads "eptir gjogfa menn skyldi haug gera til minningar"). According to the same source, monumental stones should be erected primarily for the men who had especially distinguished themselves or who had shown special manliness (Petré 1984b:186).

The historical source that exceeds all other west Nordic sources when it comes to tales about grave mounds is the Landnama Book (Rafnsson 1974:197f). It is an account of the 400 men who seized land and who are said to have colonized Iceland in the end of the 9 th century and in the beginning of the 10th. Landnama Book is considered to have come into being during the early 12 th or possibly the late 11th century (Rafnsson 1974:127, 219). Landnama Book's primary aim is an account of the acquisition of land. In Iceland there was no odal's right, but in practice the Icelandic version of ancestral land functioned as such (Rafnsson 1974:215). The burial mounds are linked to land ownership and the ancestors are thought to have their mounds near the farms. The reference to burial mounds increases in the younger versions of the Landnama Book. This fact is interpreted by Rafnsson as follows: in the beginning it was not necessary to have to resort to tales of burial mounds to maintain the rights to land (Rafnsson 1974:201). After a while, however, new owners needed the tales of settlement to explain their possession of land. People at that time thought of the burial mounds on the farms as containing specific forefathers (Rafnsson 1974: 201-203). Rafnsson gives examples which show that burial mounds were not considered to be a suitable reference to land ownership by the Christians because they were marred by a heathen connection (1974:202). It seems as if the burial mound, when the later versions of the Landnama Book were put down, stood for the vindication of and the right to landed property. The burial mounds represented what was thought to be the oldest (in heathendom) acquisition of land. The settlers often had "surnames" like "the Old," 
"the rich," or "the one who possesses wealth" "den Gamle", "den rike" eller "den som innehar öd", dvs rikedom (Rafnsson 1974: 188f). The "surname" "den Gamle" could, according to Rafnsson, be interpreted as such that the person in question had constituted the beginning of a family line where the first legal right to the land was held by "den Gamle" (Rafnsson 1974:188).

Sveinnbjørn Rafnsson is of the opinion that in the case of the Landnama Book one ascribed certain burial mounds real or fictive ancestors (1974:200). A similar pattern can be suspected as far as England is concerned. When the Christian Anglo-Saxons spoke about graves from heathen times, they did not always refer to the graves of their forefathers. As Margaret Gelling has been able to show, heathen burial mounds in boundary descriptions in Oldenglish charters can refer to mounds from the Bronze Age (Gelling 1961:18f). Certain burial mounds in England which were given Scandinavian names (personal name + mound/barrow, haugr) during the Viking Age were not graves from that time period but natural mounds or pre-Viking Age mounds (Fellows-Jensen 1992:267). It is possible that the circumstances in the Scandinavian colonization areas in England were such that it was important to be able to refer to heathen burial mounds as a way of vindicating the rights to land. If the burial mound was a manifestation of the men who possessed or would come in to possession of an inherited estate (land, farm) and thereby into possession of odal rights, was the burial mound also regarded in this way from its first appearance in the Roman Iron Age/ Migration Period? Is the establishment of cemeteries that contain mounds already in its first phase an expression of the vindication of a farm's rights? Or is this something which the mound has been ascribed in a later period - in the Viking Age or possibly the Middle Ages? Does the first appearance of mounds coincide with the time period in which the farms were established in the countryside, and have these two meanings merged in the course of time?

The burial mound is a leading feature in the cemeteries of the late Iron Age. In middle Norrland burial mounds were constructed during the early Roman Iron Age (Selinge 1977:227f). In the Mälar Valley mounds do not seem to have been erected until the later part of the Migration Period (Bennett 1987a:73). It may be that the kingsmounds kungshögarna in the Mälar Valley (i.e. mounds with a diameter of 30 metres or more) have a somewhat earlier dating than the mound in general. They seem to have been erected during above all the Migration Period (Svensson 1983:32, cp. Bennett 1987a:73). Birgit Arrhenius believes, however, that a smaller burial mound in the cemeteries at Gamla Uppsala belongs to the late Roman Iron Age/ early Migration Period (1982:72f).

In middle Norrland no large cemeteries are found, but single burial mounds occur on the farms. Of the excavated graves in middle Norrland, many belong to the Migration Period (Baudou 1988:71f). Evert Baudou has suggested that single burial mounds in middle Norrland, as well as in southwestern Norway, can represent the whole family (cp. Magnus \& Myhre 1976:267). Further, he believes that the burial mound was the object of an ancestral cult and that the mound, or mounds, was the cult centre of the farm (1989). In view of the reasoning above one could maintain that single burial mounds represent the odal line of a farm. Per Ramqvist takes up Evert Baudou's argumentation on the few graves in middle Norrland as being the object of an ancestral cult. He comments that "The argumentation is undeniably interesting, but if you exceed one side of the matter you at the same time deny the burial mounds the possibility to explain the rich variety in for example the size and contents of a burial mound from a social perspective" (Ramqvist 1990:310). There is, however, no reason to see any contradiction, as Ramqvist 
likes to withhold, between, on the one hand, the fact that a burial mound can represent both a deceased person and his/her and the family's social position, and, on the other hand, that the same burial mound can be the focus of an ancestral cult.

If it is likely that it was important to emphasize the bonds between one's dead and the ancestors from whom one had inherited the odal rights, it should be possible to find traces of such conduct in the archaeological material. One way of expressing such a mutual connection ( $\mathrm{Sw}$, samhörighet) is in the placement of one's dead in the cemeteries. In order to try to confirm such conduct, the archaeologist should look for traces in the placement of prehistoric graves that emphasize a connection between the people who had possessed an odal, or had been members of an odal line, and the survivors who wished to make this connection visible.

It is assumed that cemeteries were used continuously throughout the Iron Age, i.e. from the Roman Iron Age up to the Viking Age which is an indication in itself that the family line (Sw. odalslinjen) was unbroken. If there are several cemeteries within a village or a farm domain it may mean that the family line in some phase was broken and that the farm had passed into another family's possession. If there are several contemporaneous cemeteries, this may mean that there were several different social strata within the settlement. But it is also possible that the odal had been divided among heirs, so-called odalsskifte. If several contemporaneous cemeteries exist within a settlement, this may further indicate that the settlement already at this stage was a village with traditions (Sw. by med gammal hävd) (concerning villages as a normal feature in the Iron Age settlement structure of Sweden, see Fallgren 1993:84).

OVERLYING GRAVES - AN EXPRESSION OF MUTUAL CONNECTION?

In the archaeological literature there is a phenomenon called overlying graves (Sw. överlagrade gravar) in which graves from later times have been placed on top of older graves. With the discussion above as a background, there is reason to look at the datings of the over- and underlying graves. Furthermore, it is of interest to see whether the overlying graves consist of mounds.

Ormknös is the name of a cemetery on the island of Björkö in Lake Mälar. On the crest of the ridge where the grave-field is placed there are three big mounds (storhogar). One of these has been the object of an investigation under the supervision of Professor Birgit Arrhenius. Prior to investigation the mound was 21 metres in diameter and 2.7 metres high. The mound seems to have been constructed in two phases. During the early Roman Iron Age a mound was erected that was 17 metres in diameter and nearly 1 metre high (Arrhenius 1990:72). The mound covered a grave of which only dark discolourations and a possible grave ball $(0.4 \mathrm{~m}$ in diameter) remained. In the Viking Age the mound seems to have been enlarged to 21 metres in diameter and 2.7 metres high (Arrhenius 1990:65). The mound had been plundered and the only thing left of the supposed inhumation grave was a needle-whetstone of slate (ibid.:71). Birgit Arrhenius believes that the cemetery at Ormknös is one of several smaller cemeteries which belonged to the population on Björkö outside the towncommunity of Birka. The Viking Age burials in the cemetery at Ormknös give the impression, she states, of having been "erected as a sort of marking with the earlier ancestors rather than a trespass due to a lack of concept" (ibid.:74, my translation). Next to the discolourations in the bottom of the grave there was a charred pine $\log$ which seems to have been collected from an old and nearly untouched pine forest. Birgit Arrhenius considers it possible that the mound from the Roman Iron Age, placed on the crest of a ridge, marks a colonization phase in the early history of Björkö island (ibid.:74). If Birgit 
Arrhenius is correct in assuming that Björkö village's phase of establishment occurred during the Roman Iron Age, then the Viking Age enlargement of the mound from the Roman Iron Age could be a manner of marking a mutual connection between those who started the family line of the farm (or farms) and their Viking Age descendants. A possible parallel to the mound at Ormknös is the mound Gullhögen in Husby-Långhundra parish, Uppland, which has been under excavation under the supervision of Professor Birgit Arrhenius. This mound was erected during the early Roman Iron Age but enlarged during the Viking Age, with the result that the size of the mound is monumental (Arrhenius et. al. in print).

There are certain cases where mounds overlie several older graves. As an example, the largest mound ( 15 metres in diameter and 1.3 metres high) in the cemetery at Valsta in Norrsunda parish (Raä 59) in Uppland can be mentioned. The cemetery is under excavation under the direction of Chief Antiquarian Gunnar Andersson, UV-Stockholm, Central Board of National Antiquities (spring 1993). The mound is situated on the crest of a hill above the village. It has been placed so that it overlies five stone-settings with varied grave-forms. These are not yet excavated, but this part of the cemetery, judging by the grave-forms, may date from the Migration Period (my interpretation). During the Viking Age the mound, which cointained a cremation layer covered by a cairn, was built on top of the stone-settings. During a later part of the Viking Age further burials took place in the form of three graves with coffins that had been dug down in the cremation layer. The outer dimensions of the mound were further increased when earth-filling was added to it. Around this largest mound additional late Viking Age stone-settings had been placed; one of these is dated by a coin to the late 11 th century. In the late Viking Age, people have re-used the most monumental part of the cemetery of the settlement (oral information from Chief Antiquarian Gunnar Andersson, UV-Stockholm, Central Board of National Antiquities, February 1993). This monument could be interpreted as containing repeated expressions of mutual connection (Sw. släktsamhörighet). Arguments for this would be that the heathen and Christian graves are so closely connected with each other. Further, the mound has been chosen as the grave-form for the overlying grave, and in the late Viking Age this grave-form is once again characterised by a more monumental size than earlier. These measures could mean that the mound was looked upon as an odal-mound,"odalshög," something which is emphasized by the fact that the mound overlies some of the oldest graves in the cemetery.

The above-mentioned examples concern graves that diverge from the ordinary mounds in the cemeteries. With the help of the excavated graves from Spånga and Lovö parishes in the centre of the Mälar Valley the more "normal" cemeteries can be described (Petré 1984a b and Biuw 1992). Anita Biuw has recently presented an extensive archaeological material in her dissertation on Iron Age settlement and society in northern Spånga. In the cemeteries that she discusses the overlying grave-phenomenon occurs fairly often. She discusses especially Ärvinge, which is one of Spånga's largest medieval villages with five cemeteries from prehistoric times. Anita Biuw says of cemetery 157 in Ärvinge that "the underlying graves are often remarkably intact." Furthermore, she mentions that "the underlying graves are never younger than the Migration Period" and that "the overlying graves are always from the Viking Age" (1992:81, my translations). The underlying graves that she especially discusses are the oldest in the cemetery. When it concerns both cemeteries 156 and 157 Biuw notes that the Migration Period and Vendel Period graves lie in distinct groups in different parts of the cemetery, while the Viking Age graves are placed "totally unplanned, scattered over the whole of 
the cemetery" (ibid.:81, my translation). Based on the discussion in the beginning of the article, there is reason to regard the $\mathrm{Vi}$ king Age graves that are scattered over the cemeteries as full of meaning. My interpretation of this is that people during the Viking Age have felt it urgent to place their dead on top of and in direct contact with relations from the Roman Iron Age - Migration Period.

In Ärvinge there are also Viking Age graves that have been dug down in an occupation site dated to the Roman Iron Age - Migration Period; a pattern that also is found in Hjulsta (Biuw 1992:44, 62 and 158). The oldest graves in cemetery 156 belong to this occupation site, which in turn is overlaid by Viking Age graves (ibid.:262). Here, at Ärvinge, not only have the oldest graves been covered by Viking Age graves but also the oldest settlement. The same pattern is discernable at cemetery 157 at Ärvinge (ibid.:263). In Täby parish Anders Hedman has been able to observe that people in certain cases must have had knowledge of the position of the deserted houses and placed the graves directly on top of them (Hedman 1987:140).

The two farms connected with cemeteries 156 and 157 within Ärvinge were moved, according to Biuw, at the latest in A.D. 600650 out to the Viking Age / historical village (1992:267). In spite of the few settlement datings, it seems as if the time for the establishment of the Ärvinge farms coincides with the oldest graves in the cemetery. In the archaeological literature it is often assumed that the earliest datings from a cemetery date the establishment of the settlement as well. But this may also depend on the degree of independence of the settlement. For instance, a newly established farmstead during the first phase might continue to bury at the primary farm. But the opposite situation can prevail whereby people bury their dead at a periodic settlement, possibly at the site of some outlying activities ( $\mathrm{Sw}$. utmarksnäring).

In order to give credibility to the hypo- thesis on overlying graves as a way of showing family connection, the earliest datings of occupation sites/village grounds should be compared with the datings from each village's overlain graves. Unfortunately no general archaeological documentation was made of the village grounds in northern Spånga during the large exploitations in the 1960 s and 1970s. Only one village ground, (Lower) Kymlinge, was partly excavated (Biuw 1992:135). This has an oldest dating in the Migration Period, which corresponds in time with the oldest graves in cemetery 168 nearby (ibid.:269). This cemetery is, next after Lunda cemetery on Lovö, the largest excavated such in the Mälar Valley from the Migration and Vendel Periods (Biuw 1992:112 and Bennett 1987a:159). In Kymlinge there are no overlying graves. Perhaps the inhabitants there did not have a need to show mutual connection with the relations buried in the oldest cemetery, or perhaps the odal had passed to the care of another family. The care of the property and its dead may also have taken other expressions.

In the totally excavated cemetery at Lunda (Raä 27) on Lovö in Uppland, which dates mainly from the period A.D. $400-800$, there is a small number of Viking Age graves (Petré 1984a:15). The greater part of the Viking Age burials of the farm have been placed in another cemetery north of the farm (Raä 34, Petré 1984b:55). There are no overlying graves from the Migration and Vendel Periods in the cemetery (Raä 27); as in northern Spånga, only the Viking Age graves overlie other graves (Petré 1984b: 52). The overlying graves are all Viking Age mounds (A 11, 135 and 136). In these mounds middle-aged men seem to have been buried. One is osteologically determined as a male grave, while the other two graves have upright stones and a grave inventory that does not contradict them as being male graves. One mound overlies a female grave from A.D. 500-600 (A 11 overlies A 10). Another mound overlies three female graves with 
datings around A.D. 450 (A 135 overlies A 142, 144 and 150). And finally, one mound covers two male graves from around A.D. 400 ( A 136 overlies 148 and 151). The latter two mounds are the most apparent examples of overlying graves, and they both totally enclose the older graves (Petré 1984b: 54, fig. 17). At the Lunda cemetery some Viking Age graves are also so closely connected with the older graves that they can be viewed as secondary graves. They are all female graves and consist of cremation layers that have been scattered over older stone settings, which in turn are exclusively female graves from the period A.D. 450-500 (A $125 \mathrm{~A}+\mathrm{B}$, $126 \mathrm{~A}+\mathrm{B}, 3 \mathrm{~A}+\mathrm{B}$ and $4 \mathrm{~A}+\mathrm{B} ; 126 \mathrm{~B}$ is assigned as a male grave in Petré 1984b:137, fig. 92 , but this is, according to Bo Petré, an uncertain judgement - it can just as well be a female grave). In one of the cases the secondary grave has received a new upper part of stone (A $126 \mathrm{~A}$ ), but in the other cases this is missing.

According to Bo Petré, the farm at Lunda was established in the end of the Roman Iron Age and a cemetery was established south of the farmstead (1984b:213). The occupation is dated after the cemetery, since the prehistoric farm or village plot has been destroyed by ploughing (Petré 1984a: 18). The oldest graves (A 138, 139 and 140) are placed c. 30 metres from the farm site. Thereafter the cemetery is constructed out to the southwest, so that the Migration Period graves are situated nearest the settlement while the Vendel Period graves are found further out on the plateau. The Viking Age graves break with this pattern. Three Viking Age inhumation graves are situated in the upper part of the cemetery, near the site of the settlement. The Viking Age burials in the cemetery are "sporadic occurrences" within the period A.D. 800-1050 (Petré 1984a:15, my translation). The excavations give at hand that people during the Viking Age have returned to the custom of placing their dead close to the farmstead (Petré 1984b:190). The underlying graves are among some of the oldest graves in the cemetery; however, not the oldest in the Lunda cemetery. In Ärvinge in Spånga, correspondingly, the overlying graves consist of Viking Age graves.

The latest excavations at Lunda have given reason to alter this picture somewhat. Bo Petré has made some investigations of the Viking Age cemetery (Raä 34) situated on the northern side of the farmstead. It now appears as if the entire cemetery overlies an older cemetery from the Roman Iron Age or possibly pre-Roman Iron Age Dr. Bo Petré, Department of Archaeology, oral information, February 1993). This means that during the Viking Age the inhabitants seem to have placed their dead so that they rest upon and totally conceal the oldest phase in the Lunda farm's cemeteries from the Early Iron Age. In the cemetery that follows in the chronological chain (Raä 27), the inhabitants have covered certain older graves as well as buried some of their dead next to older graves.

A fact that could support the hypothesis about the mound as an expression for real or possible odal rights is that the mound, at least in the Spanga area, is a grave-form that is reserved especially for men (Biuw 1992: 132). The overlying Viking Age graves on the Lunda cemetery on Lovö consist, as mentioned above, of male graves in mounds. This same tendency, that primarily men were buried in mounds, can also be found in the Migration Period graves in the Mälar area that Agneta Bennett (Lagerlöf) has treated (1987a:167).

\section{THE ESTABLISHMENT OF THE ODAL RIGHTS}

The time point when the individual families mark the beginning of their odal line varies of course, but to judge from the grave material there seem to be large cemeteries with continuity from, for example, the Roman Iron Age to the Viking Age which could indicate that the family line is unbroken. There has 
not been any reason, then, to break the burial sequence by establishing a new cemetery on another spot on the property. In the examples Björkö, Valsta, Spånga and Lovö, the periods of the Roman Iron Age and Migration Period emerge as vital in a phase of establishment, either directly as in the case of Kymlinge or indirectly through the datings of (the overlying) graves. Agneta Bennett (Lagerlöf), in her survey of the c. 300 excavated Iron Age cemeteries in the Mälar Valley, has commented upon the phenomenon overlying graves. She points out that it is usually Viking Age graves that overlie graves from the Roman Iron Age or Migration Period (Bennett 1987b:155). She further shows that graves from the Roman Iron Age or Migration Period to a great extent occur in the same milieus as graves from the Late Iron Age, but that this connection is not seen between graves from the pre-Roman Iron Age and those from the Late Iron Age (Bennett 1987b:154f). If this is supposed to show a tendency in the cemetery material from the Mälar Valley, then it may mean that the Roman Iron Age and Migration Period are a central phase in the establishing of the genealogical usage ( $\mathrm{Sw}$. genealogiska hävd) that is made visible by the choice of the site for burials.

As outlined earlier, the odal right is dependent on both the family släkten and the property, the land ägan, marken. Since the farm is a condition for the odal, the question of when an odal line is established can be highlighted from another point of view, namely, by studying when a settlement marks its beginning. Thereby we have entered into one of human geography's central questions on the agrarian cultural landscape and its emergence. Mats Widgren's investigations in Östergötland have shown that the Early Iron Age settlement structure with its coherent, collective forms changes during the Late Iron Age, around A.D. 700, to a settlement structure where each farmstead can be identified as to parcel of land and site. Ulf Sporrong means that nothing contradicts this point of time as being the same for the Mälar Valley (Sporrong 1985:195, cp. Widgren 1983). To make the picture of the prehistoric farmstead easier to grasp, one can look at the change within a smaller area. Stefan Höglin, in his book "Gårdar och gärdesgårdar i Markim" (1989), has given his view of the development of the agrarian cultural landscape in Vallentuna in Uppland during the Iron Age and historical times. In his opinion, the most important event in Vallentuna probably took place during the end of the Roman Iron Age and the beginning of the Migration Period (A.D. 300-400). The area was certainly settled already in the Bronze Age / the earliest Iron Age, but sometime around A.D. 300-400 the ground was divided into inlying lands and outlying lands (Höglin 1989: 69, the same type of land division existed in eastern middle Sweden, see Widgren 1990:45). Sometime during the Late Iron Age this agrarian society changes and the scattered settlements with their organized joint properties, called hägnadslag by Höglin, leave room for what was to become a village community with village boundaries drawn over the stone fences (Höglin 1989:57). In Markim parish, for example, people have probably always inhabited the same places since the time of the origin of the landscape of stone fences, since the occupation sites are given (Höglin 1989:47). In other places in Vallentuna, however, it seems as if a couple or several of the Early Iron Age settlements have maintained a village territory. These earlier separate farms can have been connected through kinship (Höglin 1989:63 och 69).

Höglin's observations resemble the patterns that Mats Widgren found in Östergötland. Within the hägnadslag in Östergötland Widgren, nevertheless, means that there existed settlements (Sw. gårdsbruk) with separate settlement sites and fields that bore certain place-names (Widgren 1990:43). He does not, however, think that these settlements should be called farms, since in his opinion the farmstead is defined as having a distinct, 
enclosed infield (ibid.).

Is this, then, the time point - c. A.D. 700 sought after; the one at which there appears, as Ulf Sporrong expresses it, a "complete farm in the modern sense of the word" (cp. Sporrong 1985:195, my translation), when the joint properties are broken up into smaller, delimited units (cp. Widgren 1986:23)? Both Höglin and Widgren see hägnadslagens, the joint properties', dissolution as a break in continuity in comparison with the village society. Mats Widgren regards one aspect of this break as the new Late Iron Age units which place "their cemeteries straight through the cattle roads and enclosures from the Early Iron Age in such a way that they mark the outer limit of the territories known from historical times" (Widgren 1986:23). This would mean that the discordance between the older society, represented in the stone fence landscape, and the "modern" farms of the Vendel Period is so serious that it leads to a break in the maintenance of the odal. To an archaeologist, graves and cemeteries play an important part in the discussions of settlements. In view of these, it would be difficult to see the change in land usage as so radical that it would affect the odal right and belonging to a family. The moving together of a couple of the Early Iron Age farms within a jointly maintained village territory and the cemetery continuity from the Early to the Late Iron Age are phenomena that contradict a break in the continuity when the vindication of a farm ( $\mathrm{Sw}$. hävdandet av en gård) is concerned.

This argumentation is schematic - the process has assuredly been different and occurred at different times in the various parts of the Mälar Valley. In the shore-displacement areas in Roslagen the time for the establishment of the farms can, of course, be totally different than in the central areas of Vallentuna or Spånga. But it is possible that the important thing concerning the maintenance of the Viking Age farm, was not the change that occured in the Vendel Period, but that these farms instead might have looked upon themselves as being established when the division of the infield lands took place in the phase that is represented by the stone fence landscape. This means that the settlements (Sw. gårdsbruk) which function within the frame of the joint property (Sw. hägnadslaget), and which cultivate one part of the joint infield lands and bear a certain name, in many cases still exist during the Late Iron Age. But in connection with the restructuring of the cultural landscape during the Vendel Period there is among some of the farmsteads a need to mark their vindication to the land; a way of showing this vindication would be, then, the act of placing the graves on top of enclosures and cattle roads, as observed by Widgren.

\section{THE VIKING AGE - THE VISIBILITY OF THE ODAL}

The overlying graves that are discussed above are almost exclusively dated to the Viking Age. Why does it become of interest or why is it necessary to make the odal visible in the Viking Age? Is it the relocation of settlement, dated by Björn Ambrosiani to the transition from the Early to the Late Iron Age (1964:214f) and by Ulf Sporrong to $c$. A.D. 700 (1985:195), that inspires a goal to restore the bonds with the ancestors that established an odal? Or should the conduct be seen as one of the many aspects that the odal as a mentality could have?

During the Viking Age there are other ways of showing mutual connection with one's ancestors. One way of expressing this is by erecting a rune stone. Runic inscriptions are viewed here as memorial inscriptions but indirectly also as property-custodians ( $\mathrm{Sw}$. egendomsvärnare). However, not as directly as Birgit Sawyer would like to suggest, i.e. that the runic inscriptions should be regarded as declarations of property and inheritance (1988). The runic inscription communicates to neighbours and strangers the position in society that the deceased indi- 
vidual had, and to his relations the erection of the rune stone is a way of confirming position and authority. It is also a way of placing the deceased, who may have lost his life outside his own community, in a social connection. By this act the deceased and his/ her name is carved in stone and bound to the stone and to a place (Zachrisson, manuscript).

By placing the stone in the landscape of the farmstead, the erectors of the rune monuments have given certain places within the property a special dignity. The placement of the runic inscription can in itself be regarded as a formal claim ( $\mathrm{Sw}$. formell inmutning). The synthesis formed by this chosen spot and the stone with its form, ornamentation and linguistic contents can give an additional dimension to the aspect of preserving and maintaining one's odal. In a forthcoming work I will try to show that the runic inscriptions normally have been placed so that they underline the sites of a farmstead that consist of the farm itself, the boundaries to neighbouring settlements and the cemeteries (Zachrisson, manuscript). In my view, these placements aim at underlining and marking the odal mentality as it has been described above. Therefore, the runic inscriptions indirectly functioned as property-guardians ( $\mathrm{Sw}$. egendomsväktare).

What was carved in stone was probably regarded as existing forever: "as long as the stone stands and the runes spell" "så länge stenen står och runorna stavar," as it is expressed on the rune stone from Nöbbele, Östra Torsås parish in Småland (Sm16). Some rune stones have, nevertheless, been moved and others have had some part of the inscription destroyed; this possibly occurred already some generations after the erection of the stone. If instead a rock was carved, then at least there was no risk that the inscription would be moved. There is a group of runic inscriptions that in this context are especially interesting since they mention odal and the possession of landed property. It seems as if one preferred to carve inscrip- tions concerning the inheritance of villages or farms and the possession of landed property, in bed-rock. In Uppland there are examples where these types of inscriptions are placed in the close vicinity of the farmstead, or on the farm lot itself (Hillersjö U29, Runby U114, Nora U130, Veda U209, Snåttsta U331, Granby U337, Näs U348). Some inscriptions (U114, U348) mention the possession of a $b o$ - storgård, i.e. estate, like the inscription on the rock at Näs: "He owned an etstate in Torsholma and ship crew in Rolsta" "Han ägde bo $i$ Torsholma och skeppslid $i$ Rolsta" (for the concept bo, see Andræ 1960:88). The other inscriptions mention village byr, which should be understood as the more normal village or farm: U29, U130, U209, U331, U337, U729. The Snåttsta rock can serve as an example of this group: "He (Ragnfast, my remark) alone owned this village after Sigfast, his father." "Han (Ragnfast, min anm.) ägde ensam denna by efter Sigfast, sin fader." (U331).

In a formal sense these inscriptions are just like the ones in Landnama Book: he alone owned everything first, or he inhabited Mörby (Rafnsson 1974:110f). Sveinnbjørn Rafnsson considers that the similarities between Landnama Book and certain runic inscriptions indicate a similar socio-economical structure in the Nordic countries during the early medieval period (1974:113). In Iceland there are no runic inscriptions of this type but instead there is Landnama Book, which Rafnsson has characterized in a way that is of interest as a background for the runic inscriptions with statements about belonging to a farm or a village, mentioned earlier (see page 224f). "Landnamas true subject is people and land, personal names and place-names, and the relation between people and land, especially the settlers' acquisition of the land" "Landnamas egentliga ämne är människor och jord, människonamn och ortnamn, samt förhållandet mellan människor och jorden, $i$ synnerhet landnamsmännens förvärv av jorden." (Rafnsson 1974:110). Rafnsson 
means that the proprietary rights were an important force in the production of the rune stones. I hereby state that the proprietary rights certainly are significant, but that they must be regarded as one of the many aspects that the odal can take. It is a question of mentality - of belonging to a family, of legitimacy and maintenance, of guarding and caring for one's ancestors and of the mutual connection with one's landed property.

\section{MENTALITY OR THE RESPONSE}

\section{TO AN EXTERNAL PRESSURE?}

This article does not aim to give answers but to throw light upon questions which archaeologists have not taken into sufficient account. In the interpretation of the observed support for the odal there is in the article a division between, on the one hand, regarding the odal as mentality, and, on the other hand, regarding it as a response to a threat - a system in dissolution. What, in that case, does this external pressure consist of? We have reason to believe that it was possible to buy landed property during the Viking Age. This is indicated in the runic inscription on the Veda rock in Angarn parish, Uppland (kaupti pennsa by, purchased this village U209). But the extent of the "purchased land" (Sw. köpejorden ) would not have been so great as to give rise to such a reaction. The time of erecting runestones has been viewed by Ola Kyhlberg as a reaction to the disappearance of the old thing-society ( $\mathrm{Sw}$. tingssamhället) (1991:232). Is the marking of the odal and the erection of rune stones the thing yeomen's
(Sw. tingsböndernas) - the free men's - protest that the decisions no longer are formed within their controlled proximity, but instead are delivered from above or taken outside the local community?

If one instead regards the odal as a mentality, one could argue that it has been present during the whole Iron Age but that it first becomes visible to us during the Viking Age. It may be that during the Early Iron Age it found expression mainly in an ancestral cult, but that during the Viking Age it was reflected in other ways such as showing mutual connection with the dead relatives' graves and marking the importance of the farmstead through the erection of rune stones.

\section{English revised by Laura Wrang.}

I want to thank Dr. Ola Kyhlberg for constructive criticism on this article.

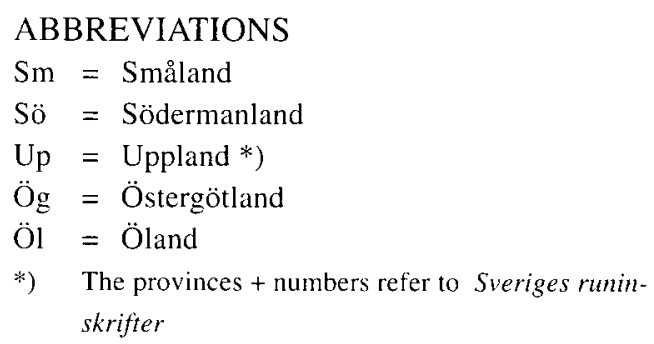

KVHAA $=$ Royal Academy of Letters and Arts

$\ddot{\mathrm{A}} \mathrm{VgL} \quad=$ the Older Västgöta Law

$\mathrm{Y} \mathrm{VgL} \quad=$ the Younger Västgöta Law

\section{REFERENCES}

Ambrosiani, B. 1964. Fornlämningar och bebyggelse. Studier i Attundalands och Södertörns förhistoria. Uppsala. Diss.

Andræ, C.G. 1960. Kurka och frälse i Sverige under aldre medeltiden. Studia Historica Upsaliensia IV. Diss.

Arrhenius, B. 1982. Snorres Asa-Etymologie und das Gräberfeld von Altuppsala. In: Kamp \& Wollasch (eds). Tradition als historische Kraft. Münster.

- 1990. Utgrävningen av den östligaste storhögen på gravfältet Ormknös, raä 111, Björkö, Adelsö sn, Uppland. Laborativ Arkeologi. 4: 65-80. Arrhenius, B. et al. Gullhögen, Husby-Långhundra 
sn, Uppland. In print.

Baudou, E. 1988. Helgedom, hus och hög. Gravfältsundersökningar och gravarkeologi. Forskning för kulturmiljövård. 3: 71-82. Riksantikvarieämbetet.

- 1989. Hög - gård - helgedom i Mellannorrland under den äldre järnåldern. Arkeologi i norr. 2. Umeå.

Bennett, A. 1987a. Graven religiös och social symbol. Theses and papers in North-European archaeology 18. Stockholm. Diss.

- 1987b. Mälarområdets järnåldersgravfält. $7000 \mathrm{ar}$ på 20 år. Arkeologiska undersökningar i Mellansverige: 143-164. Stockholm.

Birkeli, E. 1943. Fedrekult. Oslo.

- 1944. Huskult og hinsidighetstro. Skrifter utg. av Det Norske Videnskaps-Akademi i Oslo. 1943:1.

Biuw, A. 1992. Norra Spånga. Bebyggelse och samhälle under järnåldern. Stockholmsmonografier 76. Diss.

Björkvik, H. 1957. Bonde. Kulturhistoriskt lexikon för nordisk medeltid. Band 2. Ed. Andersson et al. Malmö.

Brate, E. \& Söderberg, S. 1900-06. Ölands runinskrifter Sveriges runinskrifter. 1. KVHAA. Stockholm.

- 1911-18. Östergötlands runinskrifter. Sveriges runinskrifter. 2. KVHAA. Stockholm.

Brate, E. \& Wessén, E. 1924-36. Södermanlands runinskrifter. Sveriges runinskrifter. 3. KVHAA. Stockholm.

Brendalsmo, J. \& Røthe, G. 1992. Haugbrot eller de levendes forhold til de døde - en komparativ analyse. META. 1992:1-2: 84-119.

Carlsson, L. 1935. Högsätet och hemfriden. RIG. 1935: 65-92.

Carlsson, M. 1990. En studie av undersökta treuddar i Mälardalen och Östergötland. C-uppsats. Institutionen för arkeologi. Stockholm.

Den poetiska Eddan. 1972. Translated by B. Collinder. Stockholm.

Düwel, K. 1977. Byr und bo in wikingerzeitlichen Runeninschriften aus Schweden (Diskussionsbeitrag). Das Dorf der Eisenzeit und des frühen Mittelalters: 37-40. Abhandlungen der akademie der Wissenschaft in Göttingen. Phil. - Hist. Klasse 3 folge 101.

Erikson, O. \& Strid, J-P. 1991. Runstenar. Sveriges kultur och natur 1. Malmö.

Falk, Hj. 1913. Begravelsesterminologien i oldnorsk-islandske litteratur. Festskrift til professor A. Torp. Kristiania.
Fallgren, J-H. 1993. The Concept of the Village. Current Swedish Archaeology . 1:59-86.

Fellows-Jensen, G. 1992. Cultic Place-names. Sakrale navne. NORNA-rapporter 48:265-272.

Foote, P. G. \& Wilson, D. M. 1970. The Viking Achievement. The society and culture of medieval Scandinavia. London.

Friesen, O. von. 1930. Bynamn på uppländska runstenar. Namn och Bygd. 18: 87-109.

Gelling, M. 1961. Place-Names and Anglo-Saxon Paganism. University of Birmingham Historical Journal VII:7-25.

Gurevich, A. J. 1985. Categories of Medieval Culture. London.

Gustavson, H. 1987a. Runor och runstenar. Med arkeologen Sverige runt: När Var Hur serien: 47-57.

- 1987b. Husby och Bo gård -två ortnamn och två runinskrifter. Runoroch Runinskrifter:131-144. Raä och KVHAA Symposium 8-11 sept. 1985. KVHAA Konferenser 15.

Hafström, G. 1962. Jordegendom. Kulturhistoriskt lexikon för nordisk medeltid. Band 7. Ed. Andersson et al. Malmö.

- 1967. Odalsrätt. Kulturhistoriskt lexikon för nordisk medeltid. Band 12. Ed. Andersson et al. Malmö.

Hedman, A. 1987. Östra mellansveriges järnåldersboplatser. 7000 år på 20 år. Arkeologiska undersökningar i Mellansverige :131-142. Stockholm.

Heimskringla. 1893-1900. Noregs konunga sogur af Snorri Sturluson. Ed. F. Jonsson.Samfund til Udgivelse af Gammel Nordisk Litteratur. København.

Holmbäck, ̊̊ \& Wessén, E. 1979. Svenska landskapslagar. V. Uppsala.

Holmqvist, W. 1962. Högsäte. Kulturhistoriskt lexikon för nordisk medeltid. Band 7. Ed. Andersson et al. Malmö.

Höglin, S. 1989. Gårdar och gärdesgårdar i Markim. Meddelanden Serie B 70. Kulturgeografiska institutionen, Stockholms universitet.

Jansson, S.B.F. 1964. Västmanlands runinskrifter. Sveriges runinskrifter. 13. KVHAA. Stockholm.

- 1976. Runinskrifter i Sverige. Uppsala.

- 1985. Två runstenar i Hälsingland: Malsta och Sunnanå. Filologiskt arkiv. 33.

Jansson, S.B.F. \& Wessén, E. 1940-58. Upplands runinskrifter. Sveriges runinskrifter. $6-9$. KVHAA. Stockholm. 
Kinander, R. 1935, 1961. Smålands runinskrifter. Sveriges runinskrifter. 4. KVHAA. Stockholm.

Kyhlberg, O. 1991. Gotland mellan arkeologi och historia. Theses and papers in archaeology 4. Stockholms universitet.

Larsson, M.G. 1990. Runstenar och utlandsfärder Acta archaeologica Lundensia. Series in $8^{\circ}$. Nr 18. Diss.

Lindkvist, T. 1979. Landborna $i$ Norden under äldre medeltid. Acta universitas Upsaliensis. Studia historica Upsaliensia 10. Diss.

Magnus, B. \& Myhre, B. 1986. Norges historie. 1. Forhistorien intil ca. 800 . Oslo.

Norges gamle Love indtil 1387. 1846-1849.I-III. Ed. R. Keyser \& P.A. Munch. Christiania.

Norges innskrifter med de yngre runer. III. 1954.

Olsen, M. 1926. Attegard og helligdom. Norske stednavn sosialt og religionshistoriskt belyst. Inst. for sml. kulturforskning Serie A: Forelesninger, 9a. Oslo.

Palm, R. 1992. Runor och regionalitet. Runrön 7. Diss.

Peterson, L. 1989. Svenskt runordsregister. Runrön 2. Uppsala.

Petré, B. 1984a. Arkeologiska undersökningar på Lovö. Del 3. Acta Universitas Stockholmiensis. Studies in North-European Archaeology 9. Stockholm.

- 1984b. Arkeologiska undersökningar på Lovö. Del 4. Acta Universitas Stockholmiensis. Studies in North-European Archaeology 10. Diss.

Rafnsson, S. 1974. Studier i Landnámabók. Kritiska bidrag till den isländska fristatstidens historia. Bibliotheca historica Lundensis XXXI. Diss.

Ramqvist, P. 1991. Perspektiv på regional variation och samhälle i Nordens folkvandringstid. Samfundsorganisation og Regional Variation. Norden $i$ romersk jernalder og folkevandringstid. Jysk Arkæologisk Selskabs skrifter XXVII:305-318.

Ringstad, B. 1991. Graver og ideologi. Implikasjoner fra vestnorsk folkevandringstid. Samfundsorganisation og Regional Variation. Norden $i$ romersk jernalder og folkevandringstid. Jysk Arkæologisk Selskabs skrifter XXVII: 141-150.

Robberstad. K. 1967. Odelsrett. Kulturhistoriskt lexikon för nordisk medeltid. Band 12. Ed. Andersson et. al. Malmö.

Rosén, J. 1962. Jordegendom. Kulturhistoriskt lexikon för nordisk medeltid. Band 7. Ed. An- dersson et al. Malmö.

Rønneseth, O. 1975. "Gard" und Einfriedigung Entwicklungsphasen der Agrarlandschaft Jarens. Geografiska annaler. Ser. B. Kulturgeografi. Nr 2. 1975.

Sawyer, B. 1988. Property and Inheritance in Viking Scandinavia: the Runic Evidence. Occasional Papers on Medieval Topics. 2. Alingsås.

Selinge, K-G. 1977. Järnålderns bondekultur i Västernorrland. Västernorrlands förhistoria. Härnösand.

- 1980. Fra heidnum haugi? eller vad kallades gravarna. Inventori in honorem. En vänbok till Folke Hallberg: 288-297. Stockholm.

Sjöholm, E. 1988. Sveriges medeltida lagar. Europeisk rättstradition i omvandling. Rättshistoriskt bibliotek 41 . Serie 1. Diss.

Snorre Sturluson. Norges kungasagor. 1. 1919. Translated by E. Olsson. Lund.

- Nordiska kungasagor. 1. 1991.Translated by K.G. Johansson. Stockholm.

Snorres Edda. 1978. Translated by B. Collinder. Stockholm.

Sporrong, U. 1985. Mälarbygd. Agrar bebyggelse och odling ur ett historiskt geografiskt perspektiv. Meddelanden frăn kulturgeografiska institutionen vid Stockholms universitet. Serie B 61 .

Svensson, K. 1983. Vibyhögen. Fornl. 33, Kalmar sn, Uppland. Dess forskningshistoriska, rumsliga, näringsekonomiska och sociala sammanhang. C-uppsats. Institutionen för arkeologi. Stockholm.

Sveriges runinskrifter, see Brate \& Wessén, Brate \& Söderberg, Kinander, Jansson, Jansson \& Wessén.

Taranger, A. 1907. Udsigt over den norske retshistorie. IV: 380-395. Privatrettens historie. Kristiania.

- 1913. The meaning of the words "ozal" and "skeyting" in the Old Laws of Norway. Essays in Legal History read before the International Congress of Historical Studies held in London in 1913. Ed. P. Vinogradoff:159-173.

- 1934-36. Om kongevalg i Norge i sagatiden. Historisk tidskrift, norsk. Vol. 30: 110- 166.

Zachrisson, T. Manuscript. Gård, gräns, gravfält. En studie i deponering och placering av vikingatida ädelmetalldepåer $\mathrm{i}$ Uppland och Gästrikland.

Widgren, M. 1983. Settlement and Farming Sys- 
tems in the Early Iron Age. Stockholm studies in Human Geography 3. Diss.

- 1986. Bebyggelse och markrättigheter under järnåldern. Ymer.
- 1990. Fossila åkersystem, bygränser och namn. Navn og eldre busetnad. Rapport från NORNAs femtonde symposium på Hamar 9.-11. juni 1988: 33-50. NORNA-rapporter 43. 